\title{
Helsefremmende erfaringer hos lesbiske
}

\author{
Sammendrag \\ Bakgrunn. Vi har i dag mer kunnskap \\ om hva som skaper helseproblemer \\ enn hva som skaper helse hos lesbiske. \\ Formålet med denne studien var \\ å undersøke hva lesbiske kvinner selv \\ kan oppleve som helsefremmende \\ erfaringer.
}

Materiale og metode. Utgangspunkt for artikkelen er en fokusgruppestudie med to gruppeintervjuer (med til sammen ni lesbiske i alderen 40-55 år). Deltakerne skulle være åpne om sin seksuelle orientering og fornøyd med å leve som lesbisk. Intervjuene ble tatt opp på bånd, transkribert og analysert med systematisk tekstkondensering ut fra et salutogenetisk perspektiv.

Resultater. Kvinnene fortalte om følgende typer av helsefremmende erfaringer: Å oppleve seg selv som annerledes kunne representerer muligheter og en positiv kraft. En god «komme-utprosess» kunne lede til fellesskap og strategier for mestring av utfordringer. Opplevelsen av å være fristilt fra konforme kvinnelige kjønnsrolleforventninger hadde positiv betydning for identitet og seksualitet. Friheten til å organisere parforhold og samliv på egne premisser ga nye muligheter, spesielt gjaldt det valget om å få eller ikke få barn.

Fortolkning. I helsefremmende arbeid er det nødvendig å lytte til den som best kjenner hva som er viktig i livet. Kunnskap om lesbiskes helsefremmende erfaringer kan bidra til positiv vektlegging av mestring av minoritetsstress og dessuten utfordre forståelsen av sykelighet i en marginalisert gruppe.

\section{Mona Flatval \\ monaflat@online.no \\ Seksjon for helsefag \\ Universitetet i Oslo \\ Gydas vei 8 \\ 0363 Oslo \\ Kirsti Malterud}

Allmennmedisinsk forskningsenhet Bergen Unifob Helse

I 1977 ble homoseksualitet fjernet som psykiatrisk diagnose i Norge. I debatten i forbindelse med avdiagnostiseringen ble skjevhetene i det medisinske kunnskapsgrunnlaget påpekt (1). Senere er forbindelseslinjene mellom fordommer, sykeliggjøring og seksuell orientering blitt ytterligere synliggjort (2). Den forskningsbaserte kunnskapen om lesbiskes helse er fortsatt ganske begrenset, og metodiske problemer gjør det vanskelig å trekke konklusjoner om helsetilstanden for denne minoritetsgruppen av kvinner $(3,4)$.

Ensidig vektlegging av minoriteters problemer kan bidra til å forsterke risiko- og offerperspektivet. Vi har mer kunnskap om helseproblemer enn om helsefremmende forhold hos lesbiske (4-10). Et salutogenetisk perspektiv på helse kan motvirke dette. «Salutogenese» er læren om hva som gir helse (11), med søkelys på hva som skaper helse, snarere enn hva som skaper helseproblemer. En salutogenetisk tilnærming vektlegger innsats som styrker motstandskraften, eksempelvis mobilisering av folks selvvurderte helseressurser (12). Mennesker kan ha viktig kunnskap om sine egne sterke sider, sider som legen ikke vet nok om (13). Bakgrunnen for dette prosjektet var at begge forfatterne i det kliniske arbeidet har reagert på at kunnskapsgrunnlaget om lesbiskes helse i så stor grad er problemorientert. I denne studien flytter vi derfor søkelyset fra risiko til ressurser hos lesbiske.

\section{Materiale og metode}

Problemstillingen ble belyst gjennom fokusgruppeintervjuer (14) med lesbiske som skulle være åpne og trygge $\mathrm{i}$ forhold til sin seksuelle orientering. Rekrutteringen ble gjort ved hjelp av «snøballmetoden», der deltakerne rekrutterer andre deltakere fra sin bekjentskapskrets. Vi etablerte et strategisk utvalg med variasjon i alder, grad av åpenhet og hvor lenge kvinnene hadde levd som lesbiske. To gruppeintervjuer med til sammen ni kvinner i alderen 40-55 år ble gjennomført. Vi etterspurte fortellinger om erfaringer som deltakerne selv hadde funnet helse- fremmende (15). Lydopptak av intervjuene ble transkribert og analysert med systematisk tekstkondensering $(11,16)$. Prosjektet var godkjent av regional komité for medisinsk forskningsetikk (Vest).

\section{Resultater}

Kvinnene fortalte om følgende typer av helsefremmende erfaringer: $\AA$ oppleve seg selv som annerledes kunne representerer muligheter og en positiv kraft. En god «kommeut-prosess» kunne lede til fellesskap og strategier for mestring av utfordringer. Fristillingen fra konforme kvinnelige kjønnsrolleforventninger hadde positiv betydning for identitet og seksualitet. Friheten til å organisere parforhold og samliv på egne premisser ga nye muligheter, spesielt gjaldt det valget om få eller ikke få barn. Funnene utdypes nedenfor, illustrert med sitater med referanse til deltakernummer.

\section{Annerledeshet som mulighet}

Alle fortalte om lettelsen som fulgte av «komme-ut-prosessen», der de først selv skjønte at de var lesbiske og senere fortalte dette til personer i sine omgivelser. For mange ble livet svært forandret, og flere sier at tankene om hvordan andre ville reagere var vanskeligere enn de reaksjonene som faktisk kom. Flere fremhevet at de var stolte over å være lesbiske, og noen fortalte om nyttig lærdom som de hadde med seg fra denne prosessen, selv om det også kunne oppleves som et slags press fra likesinnede. En kvinne på 44 år forteller:

Det var jo en enorm lettelse å komme ut. Det var veldig positivt, vil jeg faktisk si. A tørre ta hull på den byllen, og finne ut at det ikke var farlig. A bli tatt vel imot (deltaker $6)$.

\section{Hovedbudskap}

- I tidligere forskning om lesbiske har man lagt mer vekt på sykdom enn på helse

- Å oppleve seg selv som annerledes kan representere muligheter, stolthet, mestringsevne og fristilling - og kan styrke helsen

- Helsefremmende arbeid for mennesker i marginaliserte grupper forutsetter anerkjennelse av identitet og styrke hos den det gjelder 
Flere av deltakerne forteller om helseplager som helt eller delvis opphørte da de valgte å være åpne om sin lesbiske orientering. Helseplagene blir av kvinnene forbundet med den livsfasen da de fortsatt levde «i skapet» og belastningene knyttet til dette. En av de eldste kvinnene sa at livet var blitt helt snudd på hodet - i positiv forstand:

Jeg har blitt mindre deprimert $i$ alle fall. Og jeg klarer å spise. Jeg klarer å møte veldig mye motgang. Hele min helse har blitt hundre ganger bedre. Det er veldig få ting som gjør meg redd (deltaker 4).

Noen av kvinnene skildret gleden ved et fellesskap og gjenkjennelsen av andre lesbiske. De sa at et lesbisk miljø kunne gi mulighet til å treffe mennesker med sammenliknbare historier og erfaringer, og kanskje også ulik sosial bakgrunn. Gjennomgåtte kriser, håndtering av ulike spørsmål og fordommer kunne gi viktige erfaringer, instrumenter og kraft til å håndtere nye kriser av andre slag. Å være åpen som lesbisk kunne også gi erfaringer i å kommunisere vanskelige spørsmål. I tillegg var det flere som fremhevet kraften og styrken i det å ha tilhørighet $i$ en gruppe, noe en av deltakerne kalte en «stolthetsfremmende» faktor.

«Glede» og «fryd» er ord som brukes av om tidspunktet da de skjønte at de var lesbiske. Gleden beskrives av en av de eldste kvinnene som en slags «komme-hjem-følelse». En av deltakerne fremhevet at det for henne var en ekstra positiv erfaring å oppleve å bli glad i kroppen sin. Det første treffet med andre lesbiske på et utested ble for henne et møte med en annen kroppslighet enn hva hun hadde vært vant til. Hun forteller med begeistring at lesbiske kan representerer et annet kroppsideal enn heterofile, med følger blant annet for forholdet til klær og mote. Denne kvinnen mente dette ga henne mulighet til å unngå «heteromoten», som hun selv opplevde som kvinnefiendtlig. Hun sier dette om det første møtet:

Og da var jeg såpass voksen at jeg hadde liksom vaert litt sultefôret en stund. Det var noe av det sterkeste jeg har opplevd i livet mitt altså! Sånne skikkelige tykke smådamer som sto der og rocket vilt på scenen, med en sånn mage som heteroene bare hadde skammet seg over, ikke sant (deltaker 3).

\section{Å gjøre kvinnelighet på sin egen måte}

Å være voksen lesbisk ble av deltakerne i vår studie beskrevet som en fristilling fra konforme kvinnelige kjønnsrolleforventninger. En av kvinnene snakket om friheten til å skape sitt eget liv. Hennes opplevelse var at hun som lesbisk kan lage sine egne normer ut fra noe som kommer innenfra henne selv. Frihetsfølelsen denne kvinnen beskriver, blir også omtalt på ulike måter av flere av de andre. Det ikke å la andres synspunkter, forventninger og meninger være styrende for ens handlinger og atferd står sentralt $i$ flere av fortellingene. En kvinne la vekt på at hun nå er i kontakt med sin egen kvinnelig- het og seksualitet på en måte som for henne mer bestemmes innenfra. For henne betyr dette at det er hun selv og hennes kvinnelige kjæreste som definerer hva det vil si å være kvinne og hva seksualitet er. Ifølge henne har mange kvinnemagasiner et annet blikk på kvinnekroppen, og det er dette blikket mange heterofile kvinner har på sin egen kropp. Hun sier:

De har et sånt blikk på seg selv som objekt. De er i kroppen på en måte som avslører en form for bevissthet om seg selv som objekt. Homser er det også! De er hele tiden bevisst på den måten de poserer eller står på. Og den formen for avslappethet omkring kroppslighet. Det er noe som er veldig helsefremmende, det! Jeg har ingen muskelplager eller sainne ting (deltaker 2).

Flere av kvinnene beskrev hvordan minoritetsposisjonen kan gi en slags flerspråklighet, der de stiller spørsmål ved det som tas for gitt. Verden blir sett med andre øyne enn det som kanskje kan virke opplagt. Dette gjør det lettere å forstå andre som er i mindretall. En av kvinne sier det slik:

Det er en måte å se situasjonen på, fra et annet perspektiv. Det har gjort at jeg har en følelse av at en kan bryte andre mønstre $i$ samfunnet også. Jobbmessig, relasjonsmessig - det finnes ingen normer som jeg trenger å forholde meg til mer (deltaker 8).

\section{Å kunne gå litt mer på tvers \\ i parforhold og samliv}

Valg og dilemmaer i forhold til å ha eller få barn ble nevnt av flere av kvinnene. Også lesbiske møter forventninger om at de som kvinner også skal bli mødre og få barn. Flere av deltakerne i vår studie var barnløse, og en av disse ga uttrykk for at å leve uten barn gir muligheten for et uavhengig liv. En hevdet at mange lesbiske har flere nære vennerelasjoner enn andre - de forsvinner ikke inn i familien og blir der. En av kvinnene fortalte at da hun forsto at hun var lesbisk, tidlig i tenårene, så hun flere alternativer i forhold til hvordan hun kunne leve livet sitt - at hun kanskje ikke skulle ha barn eller at hun kunne slippe å gifte seg. En annen påpekte at for å få barn i lesbiske forhold, må man synes at det er noe spennende ved det å utforske andre måter å leve livet på. Hun var barnløs akademiker i begynnelsen av 40årene:

Nettopp det med å få barn, det er jo det litt flotte, synes jeg, med det à vare lesbisk. Da tenker jeg at det er et eksempel på hvor vi kan velge å gjøre ting på andre måter. Der har vi flere alternativ enn at det er et kjcerlighetsforhold som er utgangspunktet for felles foreldreskap for en unge (deltaker 9).

\section{Diskusjon}

\section{Forforståelse og overførbarhet}

Kanskje har det at vi selv, forskerne, er lesbiske, bidratt til å nyansere vår forforståelse av hva som kan bety noe for helsen hos denne gruppen. Vi ønsker ikke å bagatellisere helse- problemer som lesbiske kan oppleve, men utvalg, funn og tolkinger i denne studien er preget av vår salutogenetiske referanseramme. Deltakerne var voksne, ressurssterke, åpne om sin seksuelle orientering og fornøyde med å leve lesbisk, og de fortalte om positive erfaringer. Ikke alle lesbiske har det slik (5). Vi vet ikke hvor lenge det er siden deltakerne kom ut som lesbiske. Selvsagt er fortellingene farget av tiden som er gått og at de kan være fortalt mange ganger før. Dette svekker ikke validiteten av hvordan de representerer erfaringer og identitetsforståelse.

I gruppeintervjuer kan sosiale normer innad i gruppen bli styrende og slik hindre at uenigheter kan kom til uttrykk (17). Vi opplevde imidlertid diskusjonene som frie og åpne, med mange nyanser. Mange visste vi begge selv var lesbiske. Dette kunne skape økt trygghet, men også bidra til å forsterke sosiale normer. På den annen side kunne «innenfraposisjonen» kanskje gi oss et bedre utgangspunkt for å utfordre informantene på myter som kan herske blant minoriteter.

Vi tror det ikke bare er lesbiske kvinner som kan kjenne seg igjen i noen av disse historiene/opplevelsene som presenteres her, selv om våre deltakere knyttet dem til sin lesbiske identitet. Vårt materiale gir ikke grunnlag for noen mer omfattende tolking av hvordan også denne opplevelsen av kvinnelighet er kulturelt utformet. Folgerøs studie av lesbiskes og homofiles familieforståelse illustrerer imidlertid hvordan seksuell orientering kan utfordre, men samtidig også reprodusere kulturelle normer (18).

\section{Helse er mer enn fravær av sykdom}

Vår forforståelse var at alle mennesker har erfaringer om hva som kan være helsefremmende (12). Helse dreier seg også om kontroll og mestring, sosial rolleoppfyllelse og funksjonering, personlig vekst og velvære, sosial samhørighet og identitet (19). I tidligere forskning har man sett på negative effekter av lesbiskes posisjon som minoritet $(6,10)$ når det gjelder for eksempel røyking, rusbruk, overvekt og seksuell praksis (20-22). Flere studier indikerer at det er høyere risiko for hjerte- og karsykdom, ulike kreftformer og dårligere psykisk helse hos lesbiske enn hos heterofile kvinner, men sentrale feilkilder relatert til studiedesign diskuteres lite $(3,4)$. Tradisjonelle strategier for forebygging, eksempelvis måling av kolesterolnivå og mammografi, vektreduksjon samt rådgivning og testing for seksuelt overførte sykdommer og rusmisbruk, har også vært studert hos lesbiske $(23,24)$. Både Williamson og Cochran diskuterer betydningen av intervensjoner som kan motvirke stressbelastning og internalisert homofobi som risikofaktor for psykiske lidelser, men heller ikke her settes søkelyset på potensielt helsefremmende forhold ved lesbisk liv $(25,26)$.

Tidligere studier har vist sammenheng mellom en trygg lesbisk identitet, sosialt nettverk og positiv helse (27-30). Deltakere 
i vår studie fortalte om helseplager som forsvant etter hvert som de utviklet trygghet i sin seksuelle orientering. Våre informanter fortalte også om hvordan lesbisk liv kan åpne for å være glad i kroppen sin. Dette utdyper funnene $i$ en metaanalyse som viste at lesbiske hadde et mer positivt kroppsbilde hos enn heterofile kvinner (31). Dette kan tyde på at motkulturelle idealer også i Norge kan være grunnlag for en positiv identitetsutvikling hos marginaliserte grupper.

\section{Implikasjoner}

En forutsetning for målrettet helsefremmende arbeid er at pasienten føler seg sett og tatt på alvor. Vår studie understreker betydningen av at helsefremmende arbeid tar utgangspunkt i de rammene den enkelte lever sitt liv under, og at man lytter til den som best kjenner hva som er viktig i eget liv (32). Da kan det tenkes at det som tradisjonelt oppfattes som en helserisiko, kan vendes til ressurser og styrke.

Oppgitte interessekonflikter: Ingen

\section{Litteratur}

1. Heiberg AN. Homofili - sykdom eller normalvariasjon. Fokus på familien 1977; 5: 22-5

2. Malterud K. Lesbiske i medisinsk teori og praksis - et kritisk perspektiv på kunnskap og helsetjenester. I: Brantsæter MC, Eikvam T, Kjær R et al, red. Norsk homoforskning. Oslo: Universitetsforlaget, 2001: 191-213.

3. Malterud K, Bjorkman M, Flatval M et al. Epidemiological research on marginalized groups implies major validity challenges; lesbian health as an example. J Clin Epidemiol 2009. 62: 703-10.

4. Solarz AL. Lesbian health: current assessment and directions for the future. Washington D.C. Institute of Medicine (U.S.). Committee on Lesbian Health Research Priorities - National Academy Press, 1999
5. Hegna K, Kristiansen HW, Moseng BU. Levekår og livskvalitet blant lesbiske kvinner og homofile menn. Oslo: Nova, 1999

6. Diamant AL, Wold C, Spritzer K et al. Health behaviors, health status, and access to and use of health care: a population-based study of lesbian, bisexual, and heterosexual women. Arch Fam Med 2000; 9: 1043-51

7. Hall JM. Lesbians in alcohol recovery surviving childhood sexual abuse and parental substance misuse. Int J Psychiatr Nurs Res 1999; 5: 507-15.

8. Koh AS, Ross LK. Mental health issues: a comparison of lesbian, bisexual and heterosexual women. J Homosex 2006; 51: 33-57.

9. Cochran SD, Mays VM, Sullivan JG. Prevalence of mental disorders, psychological distress, and mental health services use among lesbian, gay, and bisexual adults in the United States. J Consult Clin Psychol 2003; 71: 53-61.

10. Valanis BG, Bowen DJ, Bassford T et al. Sexual orientation and health: comparisons in the women's health initiative sample. Arch Fam Med 2000; 9: 843-53

11. Antonovsky A. Unraveling the mystery of health: how people manage stress and stay well. San Francisco, CA: Jossey-Bass, 1987.

12. Hollnagel $H$, Malterud K. Shifting attention from objective risk factors to patients' self-assessed health resources: a clinical model for general practice. Fam Pract 1995; 12: 423-9.

13. Malterud K, Hollnagel H. Women's self-assessed personal health resources. Scand J Prim Health Care 1997: 15: 163-8

14. Morgan DL. Focus groups as qualitative research. 2. utg. Thousand Oaks, CA.: Sage Publications, 1997.

15. Kvale S. Det kvalitative forskningsintervju. Oslo: Ad notam Gyldendal, 1997

16. Malterud K. Kvalitative metoder i medisinsk forskning : en innføring. Oslo: Universitetsforlaget, 2003.

17. Freeman $T$. «Best practice» in focus group research: making sense of different views. J Adv Nurs 2006; 56: $491-7$.

18. Folgero T. Queer nuclear families - reproducing and transgressing heteronormativity. J Homosex 2008: 54: 124-49

19. Mæland JG, red. Forebyggende helsearbeid: i teor og praksis. 2. utg. Oslo: Universitetsforlaget, 2005.

20. Gruskin EP, Hart S, Gordon N et al. Patterns of cigarette smoking and alcohol use among lesbians and bisexual women enrolled in a large health maintenance organization. Am J Public Health 2001; 91: 976-9.

21. Koh AS, Gomez CA, Shade $S$ et al. Sexual risk factors among self-identified lesbians, bisexual women, and heterosexual women accessing primary care settings. Sex Transm Dis 2005; 32: $563-9$.

22. Boehmer U, Bowen DJ, Bauer GR. Overweight and obesity in sexual-minority women: evidence from population-based data. Am J Public Health 2007: 97: $1134-40$

23. Koh AS. Use of preventive health behaviors by lesbian, bisexual, and heterosexual women: questionnaire survey. West J Med 2000; 172: 379-84.

24. Cochran SD, Mays VM, Bowen D et al. Cancerrelated risk indicators and preventive screening behaviors among lesbians and bisexual women. Am J Public Health 2001: 91: 591-7.

25. Cochran SD. Emerging issues in research on lesbians' and gay men's mental health: does sexual orientation really matter? Am Psychol 2001; 56: 931-47.

26. Williamson IR. Internalized homophobia and health issues affecting lesbians and gay men Health Educ Res 2000; 15: 97-107.

27. Igartua KJ, Gill K, Montoro R. Internalized homophobia: a factor in depression, anxiety, and suicide in the gay and lesbian population. Can J Commun Ment Health 2003; 22: 15-30.

28. Ohnstad A. Speaking vulnerable issues into existence: their consequences for psychotherapy. Scand J Public Health Suppl 2005; 66: 24-8.

29. King LA, Smith NG. Gay and straight possible selves: goals, identity, subjective well-being, and personality development. J Pers 2004; 72: 967-94

30. Beals KP, Peplau LA. Identity support, identity devaluation, and well-being among lesbians. Psychology of Women Quarterly 2005; 29: 140-8.

31. Morrison MA, Morrison TG, Sager CL. Does body satisfaction differ between gay men and lesbian women and heterosexual men and women? A meta-analytic review. Body Image 2004: 1: 127-38.

32. Bjorkman M, Malterud K. Being lesbian - does the doctor need to know? A qualitative study about the significance of disclosure in general practice. Scand J Prim Health Care 2007; 25: 58-62.

Manuskriptet ble mottatt 27.11. 2008 og godkjent 6.8. 2009. Medisinsk redaktør Are Brean. 